\title{
Faktor Yang Mempengaruhi Pajak Perusahaan Pada Industri Dasar dan Kimia Yang Terdaftar di Bursa Efek Indonesia
}

\begin{abstract}
Author:
Hantono

Abstrak: Penelitian ini bertujuan untuk mengetahui seberapa besar faktor yang mempengaruhi pajak perusahaan pada industri dasar dan

Afiliation:

Universitas Pelita Harapan (UPH) Kampus Medan, Sumatera Utara

Corresponding email hantono_78@yahoo.com

Histori Naskah:

Submit: 99-00-9999

Accepted: 99-00-9999

Published: 99-00-9999 kimia baik secara parsial maupun secara simultan. Metode yang dilakukan dalam penelitian ini adalah metode analisis deskriptif dengan pendekatan kuantitatif. Data yang digunakan dalam penelitian ini yaitu laporan keuangan pada industri dasar dan kimia selama periode 2015 - 2019. Metode statistik yang digunakan adalah regresi linier berganda dengan melakukan uji asumsi klasik terlebih dahulu menggunakan program SPSS V.26. Berdasarkan hasil penelitian ini menunjukkan hasil bahwa data yang diuji normal dengan hasil uji normalitas yang menggunakan tabel Kolmogrov Smirnov (K-S) dan Scatterplot, uji koefisien korelasi menunjukan hubungan yang sangat kuat dan secara parsial laba operasional berpengaruh signifikan terhadap pajak penghasilan badan, biaya operasional berpengaruh signifikan terhadap pajak penghasilan badan, secara simultan laba operasional dan biaya operasional secara serempak berpengaruh terhadap variabel pajak penghasilan badan, Berdasarkan hasil terlihat $\mathrm{R}^{2}$ sebesar 0.980 berarti $98 \%$ faktor-faktor pajak penghasilan badan dapat dijelaskan oleh laba operasional dan biaya operasional sedangkan sisanya $2 \%$ dapat dijelaskan oleh faktor-faktor lain yang tidak diteliti dalam penelitian ini.
\end{abstract}

Kata kunci: laba operasional, biaya operasional, pajak penghasilan badan

\section{Pendahuluan}

Pajak merupakan salah satu sumber penerimaan terbesar bagi Indonesiadari semua sumber penerimaan negara lainnya. Salah satu jenis pajak yaitu pajak penghasilan (PPh). Pajak Penghasilan yaitu pajak yang dikenakan atas penghasilan yang diterima atau diperoleh oleh Badan seperti yang dimaksud dalam UU KUP yang dapat dikenakan langsung kepada wajib pajak,yang terdiri dari orang pribadi,badan, atau bentuk usaha tetap, menurut undang-undang No 36 Tahun 2008 tentang Pajak Penghasilan.

Dalam rangka menanggulangi dampak virus korona atau Covid-19 pemerintah menggelontorkan dana sebesar Rp 22,95 triliun dengan relaksasi pajak kepada dunia usaha dan karyawan. Stimulus yang digelontorkan antara lain pertama relaksasi Pajak Penghasilan (PPh) Pasal 21 untuk karyawan di sektor pengolahan atau manufaktur. Nantinya 100\% kewajiban pajak karyawan sektor tersebut ditanggung oleh pemerintah. Estimasi pemerintah, insentif yang dikeluarkan mencapai Rp 8,6 triliun. Stimulus ini akan diberikan kepada 19 sektor yakni industri bahan kimia dan barang dari bahan kimia, industri alat angkutan, industri makanan, industri logam dasar, industri kertas dan barang dari kertas, industri minuman, industri farmasi produk obat kimia dan obat tradisional, industri kendaraan bermotor, trailer, dan semi trailer 
(https://nasional.kontan.co.id/news/stimulus-pajak-melawan-dampak-corona-bebani-penerimaanpajak?page=all).

Pada grafik di bawah ini tercermin pada realisasi penerimaan pajak yang terus menunjukkan tren membaik, seiring dengan mulai pulihnya (recovery) ekonomi -meski masih terbatassepanjang Q3 dan Q4 pada tahun 2020 yang diperoleh informasinya dari www.kemenkeu.go.id

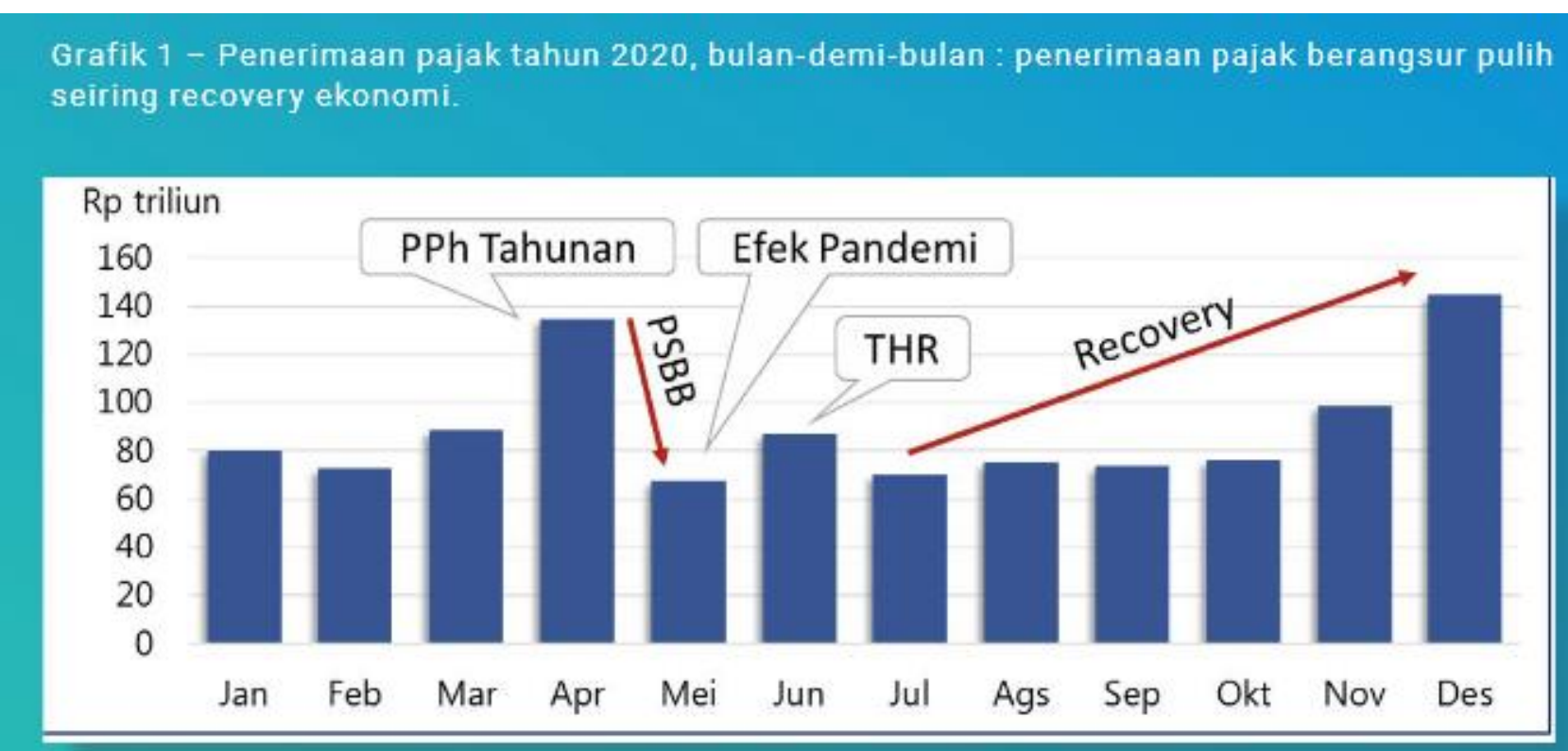

Sumber : www.kemenkeu.go.id

\section{Studi Literatur}

\section{Profitabilitas}

Profitabilitas merupakan salah satu pengukuran bagi kinerja suatu perusahaan dimana profitabilitas suatu perusahaan ini menunjukan kemampuan perusahaan untuk dapat menghasilkan laba selama periode tertentu pada tingkat penjualan, aset dan modal saham tertentu. Pengukuran rasio profitabilitas untuk mengetahui kemampuan penjualan perusahaan dalam memperoleh laba dapat menggunakan rasio margin laba bersih dan margin laba bruto. Rasio margin laba bruto merupakan rasio untuk mengukur margin laba atas penjualan (Kasmir, 2016 : 199-200). Rasio profitabilitas atau rentabilitas merupakan rasio yang menunjukkan kemampuan perusahaan dalam mencetak laba(Hantono, 2017). Ada 3 jenis profit yaitu laba bersih (net profit), laba kotor (gross profit) dan laba operasional (operating profit). Dalam penelitian ini menggunakan laba operasional dengan menggunakan indikator sebagai berikut :

\section{Biaya Operasional}

\section{Laba Operasional = Laba Kotor - Biaya Operasi}

Dalam Pasal 6 ayat (1) Undang-Undang Nomor 36 Tahun 2008 tentang pajak penghasilan dijelaskan bahwa biaya operasional yang dapat dijadikan pengurang, termasuk biaya yang secara langsung atau tidak langsung berkaitan dengan kegiatan usaha(Undang Undang Nomor 36 Tahun 2008). Biaya Operasional merupakan sumber ekonomi dalam upaya mempertahankan dan menghasilkan pendapatan. Dalam penelitian ini, biaya yang digunakan adalah biaya operasional, biaya operasional dapat diartikan sebagai suatu usaha, kegiatan atau proses input menjadi hasil 
output, sehingga dengan kata lain bahwa beban operasi dapat didefinisikan sebagai beban-beban yang terjadi dalam proses memperoleh pendapatan penjualan. Bustami dan nurlaela (2013) di dalam (Wulandari \& Fathony, 2020) mendefinisikan biaya operasional adalah biaya yang tidak berhubungan dengan proses produksi tetapi hanya mencakup biaya pemasaran dan biaya admistrasi dan umum. Biaya operasional dalam penelitian ini :

\section{Pajak Penghasilan Badan}

\section{Biaya Operasional = Biaya Penjualan + Biaya Administrasi Umum}

Pajak Penghasilan Badan merupakan pajak negara yang dikenakan pada setiap Wajib Pajak dari suatu badan usaha, baik berasal dari dalam maupun luar negeri. Pada Pasal 1 dalam Undangundang Pajak Penghasilan (UU PPh), Pajak Penghasilan merupakan Pajak yang dikenakan terhadap subjek pajak atau atas penghasilan yang diterima atau diperoleh dalam satu tahun pajak. Sehingga, Pajak Penghasilan Badan (PPh Badan) merupakan pajak yang dikenakan atas penghasilan yang diterima atau diperoleh oleh suatu badan usaha seperti yang dimaksud dalam UU KUP(Stimulus Pajak Melawan Dampak Corona Bebani Penerimaan Pajak - Ofisi Prima Consulting, n.d.).

Jenis-jenis pajak penghasilan badan antara lain:

1. Pajak Penghasilan Badan PPh Pasal 15

PPh Pasal 15 biasanya dikenakan atau dipungut dari wajib pajak yang bergerak di bidang industri pelayaran, industri pelayaran dalam negeri, industri pelayaran asing atau industri penerbangan maskapai international atau penerbangan dalam negeri, perusahaan yang terkait dengan proyek infrastruktur sarana umum seperti pembangunan jalan tol dan lain sebagainya.

2. Pajak Penghasilan Badan PPh Pasal 21

Pajak penghasilan badan pasal 21 ini sama halnya dengan pajak penghasilan badan pasal 15 , akan tetapi berdasarkan peraturan Direktur Jenderal Pajak Nomor PER-32/PJ/2015.

Dalam peraturan tersebut menjelaskan pengertian PPh Pasal 21 merupakan pajak atas penghasilan yang berupa dari honorarium, gaji, upah, tunjangan, dan pembayaran biaya lainnya dengan nama atau bahkan dalam bentuk apapun yang berkaitan dengan pekerjaan maupun jabatan, jasa, dan kegiatan lainnya yang dapat dilakukan oleh orang pribadi subjek pajak dalam negeri.

Hal ini karena wajib pajak seperti karyawan berhubungan dengan pajak penghasilan badan yang harus dibayar setiap bulannya. Perusahaan mengelola pemungutan pajak karyawan dengan memotong langsung penghasilan para karyawan tersebut dan menyetorkannya ke kas negara melalui bank persepsi. Sehingga para pekerja tidak perlu membayarkan sendiri jenis pajak ini karena sudah dibayarkan oleh perusahaan.

\section{Tarif PPh Badan normal adalah 25\% dari Penghasilan Kena Pajak}

\section{Pengaruh Laba Operasional Terhadap Pajak Penghasilan Badan}

Jika laba usaha yang diperoleh perusahaan besar, maka pajak yang terutang kepada pemerintah juga akan besar begitu pula sebaliknya(Salamah \& Yogi, 2016). Pada saat tingkat profitabilitas meningkat maka pajak penghasilan terutang menurun dikarenakan adanya perencanaan pajak yang dilakukan manajer agar dapat memaksimalkan laba ataupun dikarenakan adanya beban biaya yang harus dibayarkan sehingga dapat menurunkan laba(Jimmy \& Pratiwi, 2017).

Semakin besar margin laba bersih perusahaan akan menyebabkan kenaikkan pajak penghasilan badan (Atina et al., 2017).Tinggi rendahnya laba operasional akan berdampak pada jumlah pajak yang akan dibayarkan. Jika jumlah laba operasional mengalami kenaikan maka 
jumlah pajak yang akan dibayarkan oleh perusahaan juga akan tinggi. Sebaliknya apabila jumlah laba operasional mengalami penurunan maka jumlah pajak yang dibayarkan juga mengalami penurunan(Anggraini \& Kusufiyah, 2020).

Semakin tinggi nilai profitabilitas perusahaan, maka semakin besar PPh Badan terutang yang dibayarkan(Sumarta \& Intan, 2021). Ketika profitabilitas perusahaan meningkat maka besar pajak penghasilan perusahaan yang dibayarkan perusahaan akan semakin besar pula(Nursasmita, 2021). Berdasarkan uraian yang telah dijelaskan di atas maka dapat dibuat hipotesisnya sebagai berikut:

$\mathrm{H}_{1} \quad$ Laba Operasional berpengaruh positif terhadap Pajak Penghasilan Badan

\section{Pengaruh Biaya Operasional Terhadap Pajak Penghasilan Badan}

Semakin tinggi keuntungan yang diperoleh perusahaan maka semakin tinggi juga biaya operasional yang dikeluarkan hal tersebut tentunya secara tidak langsung terhadap Pajak Penghasilan (PPh) badan terutang perusahaan(Firdiansyah et al., 2018). Jika biaya operasional perusahaan mengalami kenaikan atau penurunan, otomatis beban pajak ikut naik atau turun tergantung besar kecilnya biaya operasional. Dari kondisi tersebut diharapkan manajemen tetap mempertahankan kinerjanya dengan memperhatikan beban pajak(Dharmayanti, 2018).

Apabila biaya operasional rendah maka menunjukkan adanya efisiensi yang dilakukan oleh pihak manajemen perusahaan terhadap beban pajak penghasilan(Widanto \& Pramudianti, 2021). Hasil dari penelitian ini sejalan dengan penelitian sebelumnya yaitu(Anam \& Zuardi, 2018), (Salamah \& Yogi, 2016), (Puspitasari et al., 2019), pada penelitian tersebut menyimpulkan bahwa secara parsial biaya operasional berpengaruh signifikan terhadap beban pajak penghasilan badan terutangnya.

Berdasarkan uraian yang telah dijelaskan di atas maka dapat dibuat hipotesisnya sebagai berikut: $\mathrm{H}_{2} \quad$ Biaya Operasional berpengaruh positif terhadap Pajak Penghasilan Badan

\section{Metode Penelitian}

Pendekatan yang digunakan dalam penelitian ini menggunakan pendekatan kuantitatif. Objek dalam penelitian ini adalah industri dan dasar kimia yang terdaftar di Bursa Efek Indonesia periode 2015 - 2019. Data yang digunakan dalam penelitian ini adalah data kuantitatif, yaitu data dalam bentuk angka-angka atau data kualitatif yang diangkakan sedangkan sumber data yang digunakan dalam penelitian ini adalah data sekunder, yaitu sumber yang tidak langsung memberikan data kepada pengumpul data contoh melalui orang lain ataupun lewat dokumen dan data sekunder dalam penelitian ini adalah laporan keuangan tahunan perusahaan yang menjadi sampel penelitian ini pada tahun 2015 - 2019 yang telah diaudit oleh kantor akuntan publik (Sugiyono,2017).

Metode pemilihan sampel yang digunakan yaitu purposive sampling dengan kriteria sebagai berikut: 1) Industri dan dasar kimia yang terdaftar di Bursa Efek Indonesia periode 2015 - 2019, 2) Industri dan dasar kimia yang terdapat laporan keuangannya selama periode $2015-2019,3$ ) Industri dan dasar kimia yang menggunakan mata uang rupiah selama periode $2015-2019$, 4) Industri dan dasar kimia yang mengalami kerugian 1 tahun selama periode 2015 - 2019. Dari kriteria tersebut diperoleh 8 perusahaan.

Metode analisis data yang dipergunakan dalam penelitian ini adalah metode analisis data kuantitatif yang diolah dengan program komputer Statistical Package for Social Science (SPSS) 26. Metode analisis data yang dilakukan pada penelitian ini meliputi statistik deskriptif, uji asumsi klasik, dan kemudian dilakukan pengujian hipotesis. Pengujian hipotesis dalam penelitian ini menggunakan analisis regresi linier berganda. Model persamaan regresi liner berganda dalam penelitian ini adalah: 
Keterangan:

$$
\mathrm{Y}=\alpha+\beta_{1} \mathrm{LO}+\beta_{2} \mathrm{BO}+\varepsilon
$$

$\mathrm{Y} \quad=$ Pajak Penghasilan Badan

LO = Laba Operasional

$\mathrm{BO}=$ Biaya Operasional

$\alpha \quad=$ Konstanta

$\beta_{1-2}=$ Koefisien Regresi

$\varepsilon \quad=$ error

Variabel penelitian ada dua independen dan dependen dimana variabel independen dalam penelitian ini adalah laba operasional $\left(\mathrm{X}_{1}\right)$ dan biaya operasional $\left(\mathrm{X}_{2}\right)$. Variabel dependen penelitian ini adalah Pajak Penghasilan Badan (Y). Metode di dalam penelitian ini menggunakan metode analis regresi linier berganda dan sebelum menggunakan metode analisis berganda lebih dahulu menggunakan uji asumsi klasik, yang terdiri dari uji normalitas, uji autokorelasi, uji multikolinieritas

- Uji Asumsi Klasik

Uji asumsi klasik dilakukan guna menguji kualitas data penelitian. Uji asumsi klasik yang dilakukan dalam penelitian ini meliputi uji normalitas, uji Multikolonieritas, uji autokorelasi, dan uji heteroskedastisitas.

- $\quad$ Uji koefisien determinasi

Uji koefisien determinasi $\left(\mathrm{R}^{2}\right)$ digunakan untuk memprediksi seberapa besar kontribusi pengaruh variabel independen terhadap variabel dependen(Ghozali,2018).

- Uji Hipotesis

a. Uji f

Uji simultan $\mathrm{F}$ digunakan untuk mengetahui apakah ada pengaruh secara bersama-sama antara variabel-variabel independen (Ghozali,2018).

b. Uji t

Uji t digunakan untuk menunjukkan seberapa jauh pengaruh satu variabel independen secara individual dalam menerangkan variabel dependen (Ghozali,2018)

\section{Hasil}

\section{Analisis Regresi Linier Berganda}

Dari data yang diperoleh kemudian dianalisis dengan menggunakan metode regresi dan dihitung menggunakan SPSS. Berikut ini merupakan hasil dari analisis regresi liniear berganda :

\section{Tabel 1}

\section{Analisis Regresi Linier Berganda}

Coefficients $^{\mathrm{a}}$

Model

Unstandardized Coefficients

\author{
Standardized \\ Coefficients \\ Beta
}

Std. Error $\mathrm{t}$

Sig. 
Jurnal Ekonomi Bisnis, Manajemen dan Akuntansi (Jebma)

Volume : 1 | Nomor 1 | Maret 2021 | E-ISSN : 2797-7161 | DOI: 10.47709/jebma.v1n1.971

\begin{tabular}{l|l|r|r|r|r|r}
\hline \hline 1 & \multicolumn{7}{c}{} & & & \\
\hline & (Constant) & -18163896883.293 & 2698059953.740 & & -6.732 & .000 \\
\cline { 2 - 7 } & LO & .270 & .004 & .917 & 68.052 & .000 \\
\cline { 2 - 7 } & BO & .028 & .004 & .101 & 7.497 & .000 \\
\hline
\end{tabular}

a. Dependent Variable: PPh_Badan

Berdasarkan hasil analisis regresi yang disajikan pada tabel 1 maka diperoleh nilai konstanta - 18163896883.29 Nilai $b_{1}=0.270$ dan $b_{2}=0.028$. Berdasarkan hasil tersebut maka dapat dibuat persamaan regresi sebagai berikut:

$\mathrm{PPh}$ Badan $=-18163896883.29+0.270$ Laba Operasional + 0.028 Biaya Operasional

\section{Uji Normalitas}

Salah satu uji normalitas yang digunakan dalam penelitian ini adalah uji statistik KolmogorovSminov (K-S). Hasil uji statistik Kolmogorov-Sminov (K-S) adalah sebagai berikut:

Tabel 2 Kolmogorov-Sminov Sebelum Transformasi

\section{One-Sample Kolmogorov-Smirnov Test}

\begin{tabular}{|c|c|c|c|}
\hline & & & $\begin{array}{l}\text { Unstandardized } \\
\text { Residual }\end{array}$ \\
\hline $\mathrm{N}$ & & & 40 \\
\hline \multirow[t]{2}{*}{ Normal Parameters ${ }^{\mathrm{a}, \mathrm{b}}$} & Mean & & .0000224 \\
\hline & Std. Deviation & & 14352392433.46935500 \\
\hline \multirow{3}{*}{$\begin{array}{l}\text { Most Extreme } \\
\text { Differences }\end{array}$} & Absolute & & .221 \\
\hline & Positive & & .103 \\
\hline & Negative & & -.221 \\
\hline Test Statistic & & & .221 \\
\hline Asymp. Sig. (2-tailed) & & & $.000^{\mathrm{c}}$ \\
\hline \multirow{3}{*}{$\begin{array}{l}\text { Monte Carlo Sig. (2- } \\
\text { tailed) }\end{array}$} & Sig. & & $.032^{d}$ \\
\hline & 99\% Confidence & Lower Bound & .028 \\
\hline & Interval & Upper Bound & .037 \\
\hline
\end{tabular}

a. Test distribution is Normal.

b. Calculated from data.

c. Lilliefors Significance Correction.

d. Based on 10000 sampled tables with starting seed 2000000.

Dari tabel di atas terlihat bahwa nilai sig nya lebih kecil dari 0.05 sementara syarat nilai signifikansinya harus lebih besar dari 0,05 maka dapat dikatakan bahwa data tersebut tidak berdistribusi normal sehingga dilakukan transformasi data seperti pada tabel di bawah ini:

Tabel 3 Kolmogorov-Sminov SetelahTransformasi One-Sample Kolmogorov-Smirnov Test

\begin{tabular}{lrr} 
& \multicolumn{2}{c}{$\begin{array}{c}\text { Unstandardized } \\
\text { Residual }\end{array}$} \\
\hline $\mathrm{N}$ & Mean & 40 \\
\hline Normal Parameters & a,b & .0000000 \\
\hline
\end{tabular}


Jurnal Ekonomi Bisnis, Manajemen dan Akuntansi (Jebma)

Volume : 1 | Nomor 1 | Maret 2021 | E-ISSN : 2797-7161 | DOI: 10.47709/jebma.v1n1.971

\begin{tabular}{llr}
\hline \hline & & \\
\cline { 2 - 4 } $\begin{array}{l}\text { Most Extreme } \\
\text { Differences }\end{array}$ & Std. Deviation & .22369880 \\
\cline { 2 - 4 } & Absolute & .117 \\
\cline { 2 - 4 } & Positive & .117 \\
\cline { 2 - 4 } & Negative & -.093 \\
\hline Test Statistic & & .117 \\
\hline Asymp. Sig. (2-tailed) & & $.176^{\mathrm{c}}$ \\
\hline Monte Carlo Sig. (2- & Sig. & $\mathbf{. 5 9 1}^{\mathbf{d}}$ \\
\cline { 2 - 4 } & 99\% Confidence & .578 \\
\hline
\end{tabular}
a. Test distribution is Normal.
b. Calculated from data.
c. Lilliefors Significance Correction.
d. Based on 10000 sampled tables with starting seed 299883525.

\section{Uji Multikolonieritas}

Pada uji multikolinearitas apabila nilai VIF kurang dari 10 dan atau nilai tolerance lebih dari 0,01 maka dapat disimpulkan dengan tegas bahwa tidak terdapat masalah multikolinearitas baik sebelum transformasi dan setelah transformasi data tidak terdapat masalah multikolinearitas seperti terlihat pada tabel di bawah ini

\section{Tabel 4 Uji Multikolinearitas Sebelum Transformasi}

\section{Coefficients $^{\mathbf{a}}$}

\begin{tabular}{llr|r} 
& \multicolumn{2}{c}{ Collinearity Statistics } \\
Model & Tolerance & \multicolumn{2}{c}{ VIF } \\
\hline 1 & LO & .376 & 2.657 \\
\cline { 2 - 5 } & BO & .376 & 2.657 \\
\hline
\end{tabular}

a. Dependent Variable: PPh_Badan

Tabel 5 Uji Multikolinearitas Setelah Transformasi

Coefficients $^{\mathrm{a}}$

\begin{tabular}{|c|c|c|c|}
\hline \multicolumn{4}{|c|}{ Coefficients ${ }^{\mathrm{a}}$} \\
\hline & & \multicolumn{2}{|c|}{ Collinearity Statistics } \\
\hline \multicolumn{2}{|c|}{ Model } & Tolerance & VIF \\
\hline \multirow[t]{2}{*}{1} & ln_LO & .374 & 2.674 \\
\hline & ln_BO & .374 & 2.674 \\
\hline
\end{tabular}

a. Dependent Variable: In_PPh_Badan

\section{Uji Autokorelasi}

Uji autokorelasi adalah untuk melihat apakah terjadi korelasi antara suatu periode $\mathrm{t}$ dengan periode sebelumnya $(\mathrm{t}-1)$. Pada penelitian ini penulis menggunakan uji run test untuk melakukan uji autokorelasi seperti pada tabel di bawah ini

\section{Tabel 6 Uji Autokorelasi Sebelum Transformasi Data Runs Test}


Jurnal Ekonomi Bisnis, Manajemen dan Akuntansi (Jebma)

Volume : 1 | Nomor 1 | Maret 2021 | E-ISSN : 2797-7161 |DOI: 10.47709/jebma.v1n1.971

Unstandardized Residual

\begin{tabular}{lr}
\hline Test Value $^{\mathrm{a}}$ & 3953574971.22160 \\
\hline Cases $<$ Test Value & 19 \\
\hline Cases >= Test Value & 21 \\
\hline Total Cases & 40 \\
\hline Number of Runs & 7 \\
\hline Z & -4.320 \\
\hline Asymp. Sig. (2-tailed) & $\mathbf{. 0 0 0}$
\end{tabular}

a. Median

Pada tabel di atas terlihat data pada uji autokorelasi memiliki angka signifikansi masih di bawah dari 0.05 sehingga akan ditransformasi datanya agar berdistribusi normal seperti pada tabel di bawah ini

Tabel 7 Uji Autokorelasi Setelah Transformasi Data Runs Test

\begin{tabular}{lr} 
& Unstandardized Residual \\
\hline Test Value & -.00122 \\
\hline Cases $<$ Test Value & 20 \\
\hline Cases >= Test Value & 20 \\
\hline Total Cases & 40 \\
\hline Number of Runs & 15 \\
\hline Z & -1.762 \\
\hline Asymp. Sig. (2-tailed) & $\mathbf{. 0 7 8}$ \\
\hline
\end{tabular}

a. Median

Pada tabel di atas terlihat data pada uji autokorelasi memiliki angka signifikansi masih di atas dari 0.05 sehingga datanya sudah berdistribusi normal.

\section{Uji Heteroskedastisitas}

Uji Heteroskedastisitas bertujuan untuk menguji apakah dalam model regresi terjadi ketidaksamaan varians dari residual pengamatan satu ke pengamatan yang lain yang berbeda. Dalam uji heteroskedastisitas sebelum transformasi data terlihat titik - titik menumpuk dan tidak merata penyebarannya yang bisa dilihat pada grafik di bawah ini

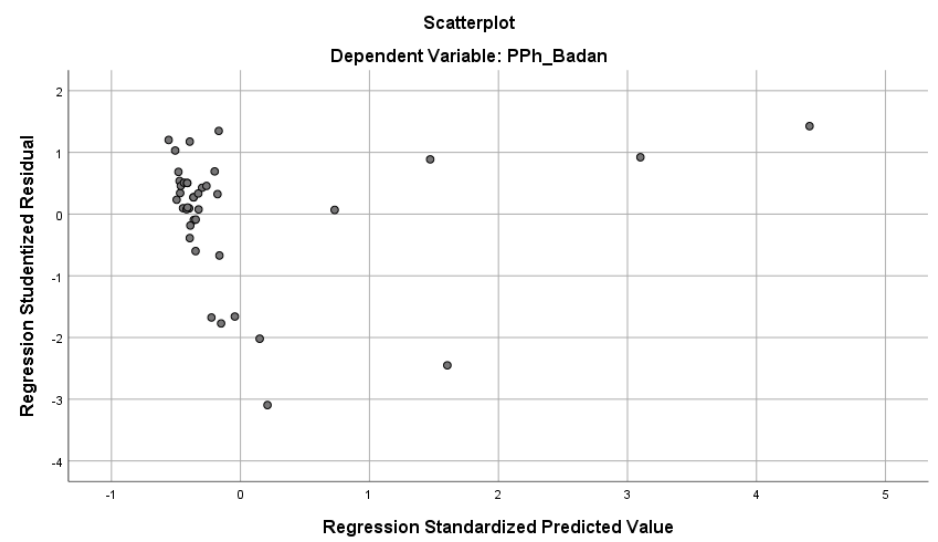




\section{Grafik 1. Uji Heteroskedasitas Sebelum Transformasi Data}

Pada grafik terlihat data tidak berdistribusi normal sehingga dilakukan transformasi data seperti pada grafik di bawah ini:

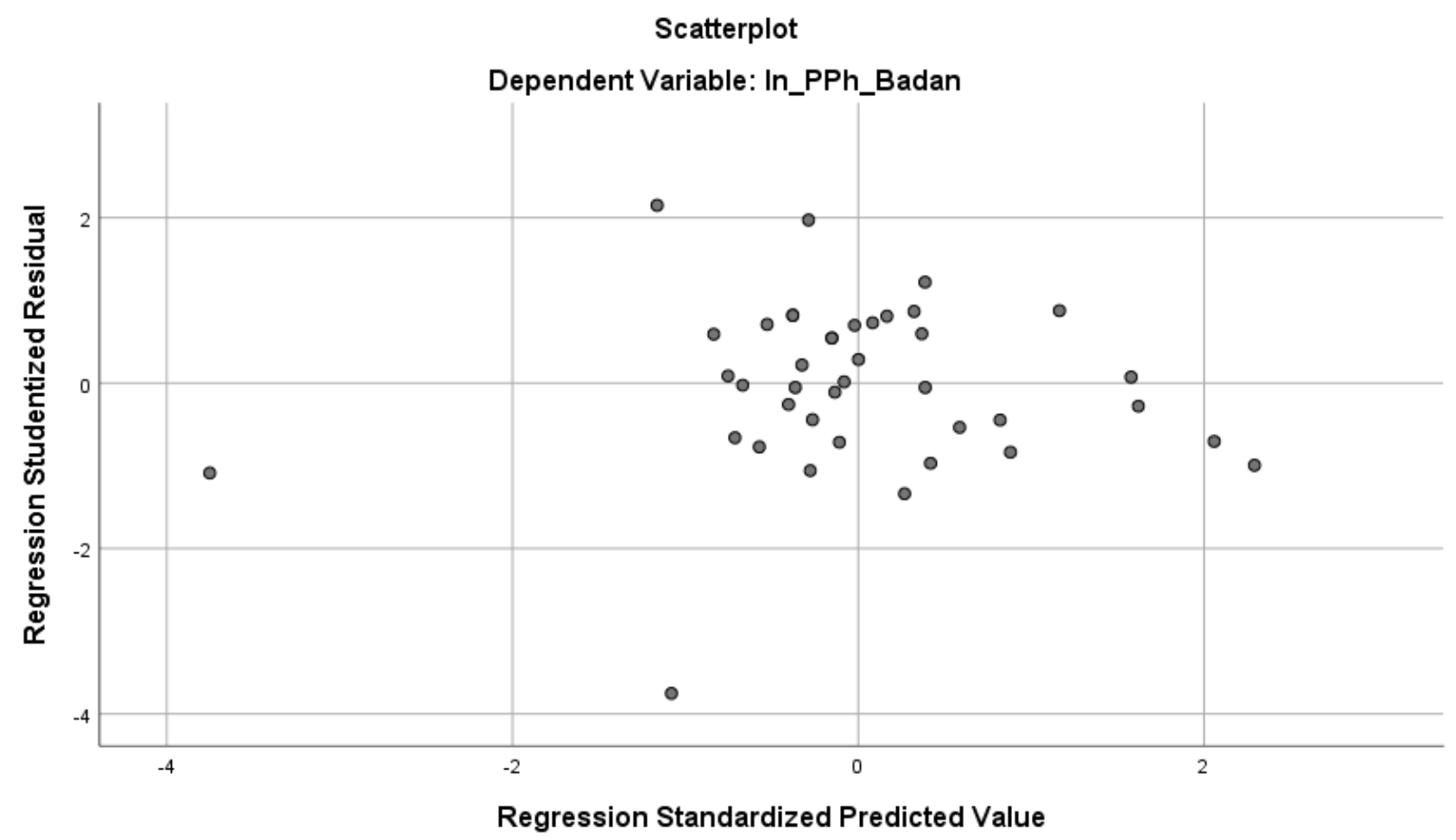

Grafik 2. Uji Heteroskedasitas Setelah Transformasi Data

Berdasarkan grafik scatterplot menunjukkan bahwa titik-titik tersebar secara acak (tidak berpola) baik di atas maupun di bawah angka 0 (nol) pada sumbu Y sehingga dapat disimpulkan bahwa model persamaan dalam penelitian ini telah memenuhi asumsi homoskedastisitas atau tidak terjadi heteroskedastisitas.

\section{Uji Koefisien Determinasi}

Koefesiensi determinasi $\left(\mathrm{R}^{2}\right)$ digunakan untuk mengukur seberapa baik garis regresi sesuai dengan data aktualnya (goodness of fit).Koefisiensi determinasi ini mengukur prosentase total varian variabel dependen $\mathrm{Y}$ yang dijelaskan oleh variabel independen di dalam garis regresi yang terlihat pada tabel di bawah ini

\section{Tabel 8 Uji Koefisien Determinasi}

\begin{tabular}{|c|c|c|c|c|c|}
\hline \multicolumn{6}{|c|}{ Model Summary } \\
\hline Model & $\mathrm{R}$ & R Square & Adjusted R Square & $\begin{array}{l}\text { Std. Error of the } \\
\text { Estimate }\end{array}$ & Durbin-Watson \\
\hline 1 & $.990^{\mathrm{a}}$ & .980 & .979 & .22967 & 1.370 \\
\hline
\end{tabular}

a. Predictors: (Constant), ln_BO, ln_LO

b. Dependent Variable: ln_PPh_Badan 
Pada tabel di atas terlihat R Square sebesar 0.980 berarti $98 \%$ faktor-faktor pajak penghasilan badan dapat dijelaskan oleh laba operasional dan biaya operasional sedangkan sisanya $2 \%$ dapat di jelaskan oleh faktor-faktor lain yang tidak diteliti dalam penelitian ini.

\section{Uji f}

Uji f merupakan uji koefisien regresi yang dilakukan secara simultan dan serentak dan pada metode pengujian statistika dengan teknik tersebut biasanya digunakan untuk membandingkan antara dua atau lebih objek data sehingga dalam pengujiannya setiap objek atau data memiliki perlakuan yang berulang demi menentukan besar kecilnya variansi.

Tabel 9 Uji f

\begin{tabular}{|c|c|c|c|c|c|c|}
\hline \multicolumn{7}{|c|}{ ANOVA $^{a}$} \\
\hline \multicolumn{2}{|l|}{ Model } & $\begin{array}{l}\text { Sum of } \\
\text { Squares }\end{array}$ & Df & Mean Square & $\mathrm{F}$ & Sig. \\
\hline \multirow[t]{3}{*}{1} & Regression & 97.036 & 2 & 48.518 & 919.837 & $.000^{b}$ \\
\hline & Residual & 1.952 & 37 & .053 & & \\
\hline & Total & 98.987 & 39 & & & \\
\hline
\end{tabular}

a. Dependent Variable: ln_PPh_Badan

b. Predictors: (Constant), ln_BO, ln_LO

Nilai $\mathrm{f}$ hitung adalah 919.837dengan tingkat signifikansi 0,000 sedangkan $\mathrm{f}_{\text {tabel }}$ pada alpha atau tingkat kepercayaan 95\% $(\alpha=0,05)$ adalah 3,06. Sehingga disimpulkan bahwa $f_{\text {hitung }}>f_{\text {tabel }}$ $(919.837>3.23)$ dan tingkat signifikansinya $0.000<0.05$ menunjukkan bahwa pengaruh variabel bebas yaitu laba operasional dan biaya operasional secara serempak adalah signifikan terhadap pajak penghasilan badan sehingga $\mathrm{H}_{0}$ ditolak dan $\mathrm{H}_{1}$ diterima yang berarti bahwa variabel laba operasional dan biaya operasional secara serempak berpengaruh terhadap variabel pajak penghasilan badan.

\section{Uji t (Parsial)}

Uji statistik t pada dasarnya menunjukkan seberapa jauh pengaruh satu variabel independen secara individual dalam menerangkan variasi variabel dependen. Dari hasil pengujian analisis regresi diketahui nilai t hitung sebagai berikut:

\section{Tabel 10 Uji t}

Coefficients $^{\mathrm{a}}$

\begin{tabular}{|c|c|c|c|c|c|c|}
\hline \multirow[b]{3}{*}{ Model } & \multicolumn{6}{|c|}{ Coefficients ${ }^{\mathrm{a}}$} \\
\hline & & Unstandardized & Coefficients & $\begin{array}{l}\text { Standardized } \\
\text { Coefficients }\end{array}$ & & \\
\hline & & $\mathrm{B}$ & Std. Error & Beta & $\mathrm{T}$ & Sig. \\
\hline 1 & (Constant) & -18163896883.293 & 2698059953.740 & & -6.732 & .000 \\
\hline & $\mathrm{LO}$ & .270 & .004 & .917 & 68.052 & .000 \\
\hline & $\mathrm{BO}$ & .028 & .004 & .101 & 7.497 & .000 \\
\hline
\end{tabular}

a. Dependent Variable: PPh_Badan

Pada tabel di atas terlihat pada variabel laba operasional $\left(\mathrm{X}_{1}\right)$ dengan nilai thitung sebesar 68.052 dengan tarif signifikansi 0.000 maka hasil yang diperoleh dari perbandingan $t_{\text {hitung }}$ dengan $\mathrm{t}_{\text {tabel }}$ adalah $\mathrm{t}_{\text {hitung }}>\mathrm{t}_{\text {tabel }}(68.052>2.021)$, sehingga pada tingkat kekeliruan $5 \% \mathrm{H}_{0}$ ditolak dan $\mathrm{H}_{1}$ 
diterima yang berarti variabel laba operasional berpengaruh signifikan terhadap pajak penghasilan badan.

Pada tabel di atas terlihat pada variabel biaya operasional $\left(\mathrm{X}_{2}\right)$ dengan nilai $\mathrm{t}_{\text {hitung }}$ sebesar 7.497 dengan tarif signifikansi 0.000. Maka hasil yang diperoleh dari perbandingan $t_{\text {hitung }}$ dengan $\mathrm{t}_{\text {tabel }}$ adalah $\mathrm{t}_{\text {hitung }}>\mathrm{t}_{\text {tabel }}(7.497>2.021)$, sehingga pada tingkat kekeliruan $5 \% \mathrm{H}_{0}$ ditolak dan $\mathrm{H}_{1}$ diterima yang berarti variabel biaya operasional berpengaruh signifikan terhadap pajak penghasilan badan.

\section{Pembahasan}

1. Uji Secara Parsial

a. Laba operasional berpengaruh signifikan terhadap pajak penghasilan badan.

Hasil uji hipotesis menunjukkan bahwa laba operasional berpengaruh signifikan terhadap pajak penghasilan badan Hal ini terjadi karena nilai $t_{\text {hitung }}$ sebesar 68.052 dengan tarif signifikansi 0.000 maka hasil yang diperoleh dari perbandingan $t_{\text {hitung }}$ dengan $t_{\text {tabel }}$ adalah $t_{\text {hitung }}>\mathrm{t}_{\text {tabel }}(68.052>2.021)$, sehingga pada tingkat kekeliruan $5 \% \mathrm{H}_{0}$ ditolak dan $\mathrm{H}_{1}$ diterima yang berarti variabel laba operasional berpengaruh signifikan terhadap pajak penghasilan badan. Penelitian ini sejalan dengan penelitian yang dilakukan oleh (Salamah \& Yogi, 2016), (Jimmy \& Pratiwi, 2017), (Atina et al., 2017), (Anggraini \& Kusufiyah, 2020), (Sumarta \& Intan, 2021), (Nursasmita, 2021). Hal ini disebabkan apabila pendapatan yang diperoleh perusahaan mengalami kenaikan maka secara otomatis beban pajak ikut mengalami kenaikan.

b. Biaya operasional berpengaruh signifikan terhadap pajak penghasilan badan.

Hasil uji hipotesis menunjukkan bahwa biaya operasional berpengaruh signifikan terhadap pajak penghasilan badan Hal ini terjadi karena nilai thitung sebesar 68.052 dengan tarif signifikansi 0.000 maka hasil yang diperoleh dari perbandingan nilai thitung sebesar 7.497 dengan tarif signifikansi 0.000. Maka hasil yang diperoleh dari perbandingan thitung dengan $\mathrm{t}_{\text {tabel }}$ adalah $\mathrm{t}_{\text {hitung }}>\mathrm{t}_{\text {tabel }}(7.497>2.021)$, sehingga pada tingkat kekeliruan $5 \% \mathrm{H}_{0}$ ditolak dan $\mathrm{H}_{1}$ diterima yang berarti variabel biaya operasional berpengaruh signifikan terhadap pajak penghasilan badan. . Penelitian ini sejalan dengan penelitian yang dilakukan oleh (Firdiansyah et al., 2018), (Dharmayanti, 2018), (Widanto \& Pramudianti, 2021), (Anam \& Zuardi, 2018), (Salamah \& Yogi, 2016), (Puspitasari et al., 2019). Hal ini disebabkan apabila biaya operasional perusahaan mengalami kenaikan atau penurunan sehingga akan secara otomatis menyebabkan beban pajak mengalami kenaikan atau turun tergantung besar kecilnya biaya operasional.

2. Uji Determinasi

Uji determinasi digunakan untuk mengukur tingkat kemampuan model dalam menerangkan variabel independen, tapi karena $\mathrm{R}^{2}$ mengandung kelemahan mendasar, yaitu adanya bias terhadap jumlah variabel independen yang dimasukkan ke dalam model, maka dalam penelitian ini menggunakan $\mathrm{R}^{2}$ berkisar antara 0 dan 1 . Jika nilai $\mathrm{R}^{2}$ semakin mendekati 1 maka semakin baik kemampuan model tersebut dalam menjelaskan variabel dependen. Berdasarkan hasil terlihat $\mathrm{R}^{2}$ sebesar 0.980 berarti $98 \%$ faktor-faktor pajak penghasilan badan dapat dijelaskan oleh laba operasional dan biaya operasional sedangkan sisanya $2 \%$ dapat dijelaskan oleh faktor-faktor lain yang tidak diteliti dalam penelitian ini.

3. Uji Secara Simultan 
Uji f digunakan untuk menguji tingkat pengaruh variabel independen terhadap variabel dependen secara bersama-sama. Dalam uji $\mathrm{F}$ kesimpulan yang diambil adalah dengan melihat signifikansi $5 \%$ atau 0,05 . Berdasarkan nilai $\mathrm{f}_{\text {hitung }}$ adalah 919.837 dengan tingkat signifikansi 0,000 sedangkan $\mathrm{f}_{\text {tabel }}$ pada alpha atau tingkat kepercayaan $95 \%(\alpha=0,05)$ adalah 3,06. Sehingga disimpulkan bahwa $\mathrm{f}_{\text {hitung }}>\mathrm{f}_{\text {tabel }}(919.837>3.23)$ dan tingkat signifikansinya $0.000<0.05$ menunjukkan bahwa pengaruh variabel bebas yaitu laba operasional dan biaya operasional secara serempak adalah signifikan terhadap pajak penghasilan badan sehingga $\mathrm{H}_{0}$ ditolak dan $\mathrm{H}_{1}$ diterima yang berarti bahwa variabel laba operasional dan biaya operasional secara serempak berpengaruh terhadap variabel pajak penghasilan badan.

\section{Kesimpulan}

Kesimpulan dari hasil penelitian yang telah dilakukan sebagai berikut:

a. Laba operasional berpengaruh signifikan terhadap pajak penghasilan badan yang dapat

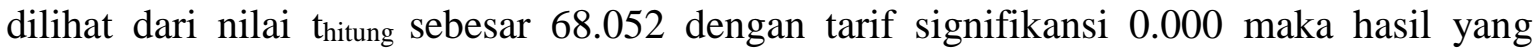
diperoleh dari perbandingan $t_{\text {hitung }}$ dengan $t_{\text {tabel }}$ adalah $t_{\text {hitung }}>t_{\text {tabel }}(68.052>2.021)$.

b. Biaya operasional berpengaruh signifikan terhadap pajak penghasilan badan yang dapat dilihat dari nilai thitung sebesar 68.052 dengan tarif signifikansi 0.000 maka hasil yang diperoleh dari perbandingan nilai thitung sebesar 7.497 dengan tarif signifikansi 0.000. Maka hasil yang diperoleh dari perbandingan thitung dengan $t_{\text {tabel }}$ adalah thitung $>t_{\text {tabel }}(7.497>2.021)$.

\section{Referensi}

Anam, C., \& Zuardi, L. R. (2018). Analisis Rasio Likuiditas, Rasio Solvabilitas, dan Biaya Operasional Terhadap Pajak Penghasilan Badan Terutang (Sektor Pertambangan Di BEI Tahun 2011-2016. Margin Eco, 2(1), 43-68.

Anggraini, D., \& Kusufiyah, Y. V. (2020). Dampak Profitabilitas, Leverage dan Biaya Operasional Terhadap Pajak Penghasilan Badan (Studi Empiris Pada Perusahaan Food and Beverage Yang Terdaftar di Bursa Efek Indonesia). Jurnal Ekonomi Dan Bisnis Dharma Andalas, 22(1), 32-47.

Atina, I., Harimurti, F., \& Kristianto, D. (2017). Pengaruh Profitabilitas Dan Biaya Operasional Terhadap PPh Badan Perusahaan Makanan Dan Minuman Di BEI (Periode 2013-2015). Jurnal Akuntansi Dan Sistem Teknologi Informasi, 12(3), 323-330.

Dharmayanti, N. (2018). Pengaruh Pendapatan Dan Biaya Operasional Terhadap Beban Pajak Pada Pt Jembo Cable Company Tbk. Jurnal Riset Akuntansi Terpadu, 11(2), 229-237. https://doi.org/10.35448/jrat.v11i2.4262

Dyah Ayu Linda Puspitasari, N. A. (2019). Pengaruh Profitabilitas Likuiditas dan Biaya Operasional Terhadap Pajak Penghasilan Badan (Studi Pada Perusahaan Manufaktur Sub Sektor Industri Barang Konsumsi Yang Terdaftar di Bursa Efek Indonesia Periode Tahun 2015-2017). Simba Seminar Inovasi Manajemen, Bisnis Dan Akuntansi I, 15. https://www.infodesign.org.br/infodesign/article/view/355\%0Ahttp://www.abergo.org.br/re vista/index.php/ae/article/view/731\%0Ahttp://www.abergo.org.br/revista/index.php/ae/artic le/view/269\%0Ahttp://www.abergo.org.br/revista/index.php/ae/article/view/106 
Eksandy, A. (2017). Pengaruh Komisaris Independen, Komite Audit, dan Kualitas Audit Terhadap Penghindaran Pajak (Tax Avoidance) (Studi Empiris Pada Sektor Industri Barang Konsumsi yang terdaftar di Bursa Efek Indonesia Periode 2010-2014). Competitive Jurnal Akuntansi Dan Keuangan, 1(1), 1. https://doi.org/10.31000/competitive.v1i1.96

Firdiansyah, A. ., Sudarmanto, E., \& Fadillah, H. (2018). Pengaruh Profitabilitas dan Biaya Operasional Terhadap Baban Pajak Penghasilan Badan Terutang Pada Perusahaan Perdagangab Eceran Yang Terdaftar Di BEI (Periode 2013-2017). Jurnal Akuntansi Universitas Pakuan, 1-13.

Ghozali, Imam. 2018. Aplikasi Analisis Multivariative Dengan Program IBM SPSS. Semarang: Universitas Diponegoro

Hantono. (2017). Konsep Analisa Laporan Keuangan Dengan Pendekatan Rasio Dan SPSS. Deepublish Publisher.

Jimmy, \& Pratiwi, R. (2017). Pengaruh Profitabilitas dan Biaya Operasional Terhadap Pajak Penghasilan Badan ( Studi Empiris Pada Perusahaan Pertambangan Yang Terdaftar di Bursa Efek Indonesia. Jurnal Akuntansi STIE Multi Data Palembang, 1-12.

Nursasmita, E., Akuntansi, J., Surabaya, U. N., Ketintang, J., Margin, N. P., \& Penghasilan, P. (2021). Pengaruh Struktur Modal, Profitabilitas dan Biaya Operasional terhadap Pajak Penghasilan Badan Terutang. Jurnal Akuntansi Unesa, 9(3).

Salamah, A. A., \& Yogi, M. G. W. E. N. P. K. (2016). Pengaruh Profitabilitas dan Biaya Operasional Terhadap Pajak Penghasilan Badan (Studi Pada Perusahaan Manufaktur Yang Terdaftar di Bursa Fek Indonesia PERIODE 2012-2014). Jurnal Perpajakan (JEJAK)| Vol. 9 No. 1 2016, 4(4), 1-10.

Stimulus Pajak Melawan Dampak Corona Bebani Penerimaan Pajak - Ofisi Prima Consulting. (n.d.).

Sumarta, R., \& Intan, A. U. (2021). Faktor-Faktor Yang Memengaruhi PPh Badan Terutang Pada Perusahaan Manufaktur di Bursa Efek Indonesia. Media Bisnis, 12(2), 175-184. https://doi.org/10.34208/mb.v12i2.922

Undang Undang Nomor 36 Tahun 2008. (2008). Perubahan Keempat Atas Undang-Undang Nomor 7 Tahun 1983 Tentang Pajak Penghasilan. May.

Widanto, R., \& Pramudianti, M. (2021). Pengaruh likuiditas, solvabilitas, profitabilitas dan biaya operasional terhadap beban pajak penghasilan badan terutang ( Pada Perusahaan Manufaktur Sektor Industri Barang Konsumsi yang Terdaftar di BEI Tahun 2016-2017 ). Liability, 03(1), 36-54.

Wulandari, Yulianti\& Aditya Achmad Fathony.(2020). Pengaruh Biaya Produksi Dan Biaya Operasional Terhadap Laba Bersih Pada Pt.Perkebunan Nusantara VIII. Jurnal Ilmiah Akuntansi, 11(1), 43-54. 